Available online at: https://proceeding.researchsynergypress.com/index.php/rsfconferenceseries1

RSF Conference Series: Business, Management and Social Sciences

e-ISSN 2807-5803/p-ISSN 2807-6699

Volume 1Number 5 (2021): 84-96

\title{
Comparison of Indonesian Banking Regulation for Integrated Governance, Risk Management, Compliance with its ISO Counterparts
}

\author{
Nitha Pricillia \\ Universitas Katolik Parahyangan, Indonesia
}

\begin{abstract}
The research is aiming at obtaining understanding and assurance whether the regulation of Indonesia Financial Services Authority (or Otoritas Jasa Keuangan/OJK) for banking industry on Governance, Risk Management, and Compliance (GRC) in Indonesia are compatible with the requirements and suggested practices of ISO 37000/DIS on Governance, ISO 31000:2018 Risk Management, and ISO 37301: Compliance Management as international standards for Governance, Risk, and Compliance (GRC). The regulatory requirements as set forth by Indonesian FSA to banking industry for integrated GRC have all been compatible with all the elements of ISO 37000, ISO 31000:2018, and ISO 37301. This study utilizes a comparative study method, which is conducted by assessing the similarities and differences between two standards or regulations, or in this study, between Indonesia Financial Services Authority Regulation, or Peraturan Otoritas Jasa Keuangan (POJK) on Governance, Risk Management and Compliance (GRC), with their ISO Standards counterparts. The result is expected to show the degree of fitness of Indonesian banking regulations with these ISO standards. There is only a very small number of studies have been done in the light of calibrating the Indonesian banking regulation in Governance, Risk Management and Compliance (GRC) with their ISO counterparts. Therefore, the result of this paper could be used as generic inputs and considerations for banks which have initiated their integrated GRC practices, and/or just recently commenced, and/or improving their practices more effectively. Whereas the study provides general understanding and assurance of the compatibility, it is not supported yet by empirical evidence of how banks practically exercise the implementation of integrated GRC based on ISO 37000, ISO 31000, and ISO 37301 and how do they conduct calibration efforts to its efficacy. Therefore, it is recommended to conduct such empirical case study in several banks in Indonesia as further study. Further, a field study such as interviews and surveys with Indonesian banking professionals could also be performed to provide additional perspectives on how integrated GRC is implemented in Indonesian banking.
\end{abstract}

Keywords: GRC banking, ISO banking, POJK ISO, GRC ISO, Indonesia banking regulation, banking regulation, risk management banking, governance banking, compliance banking.

This is an open access article under the CC-BY-NC license.

\section{INTRODUCTION}

Banking industry plays an important part in the development of an economy through its role as financial intermediaries. A good corporate governance, accompanied by an effective management of risk and regulatory compliance are the most critical factors determining bank's performance.

ISO 37000/DIS, ISO 31000:2018 Risk Management Principles and Guidelines, and ISO 37301: Compliance Management System has been issued by International Standardization for Organization or ISO as international standards for Governance, Risk Management and Compliance (GRC), respectively. These standards are the most widely recognized around the world to guide the GRC practice, regardless of industry. These ISO guidance could be used separately, however they are also essentially fit to each other and therefore could be used as a cohesive reference for the implementation of integrated GRC.

However, there is not enough proof whether these standards have also been extensively used in banking industry as the standards for integrated GRC, as is the case in Indonesian banking industry. 
Indonesian banks are supervised and regulated by Indonesia's Financial Services Authority (IFSA). IFSA have the authority in monitoring Indonesian bank's performance, and the regulation they issued is called Indonesia Financial Services Authority Regulation, or Peraturan Otoritas Jasa Keuangan (POJK). Further, Indonesian banks also adopted BASEL III (OJK Press Release, December 8, 2017). As financial crises hit the financial services industry between 2007 and 2009, Basel Committee on Banking Supervision (BCBS), a group of world's central banks, developed a set of regulations aiming at strengthening banks'supervision and risk management so that they could endure the pressure should another economic downturn happens in the future. These were done through ensuring that financial institutions have enough capital on account to meet obligations and absorb unexpected losses (BCBS, n.d).

Banking industry has long been one of the most regulated industry in the world. Therefore, banks need to gain understanding whether these regulations are matched, complement, or contradict with the relatively new ISO standards. This understanding is needed so that banks will be able to allocate their resources effectively and avoid duplication of effort in complying to both regulations.

As the case for Indonesian banking, there is not enough data that proves if ISO international standards are well-accepted and compatible with Indonesia banking regulations.

Therefore, this study is trying to answer the question on the degree of compatibility of Indonesian Banking Regulation (POJK) in Governance, Risk Management and Compliance, with their ISO counterparts, which are ISO 37000/DIS Guidance for Governance, ISO 31000:2018 for Risk Management, and ISO 37301 for Compliance.

\section{LITERATURE REVIEW}

\section{Governance, Risk Management, Compliance and Bank's Performance}

During the past few years, the financial services industry especially banking has seen an extraordinary rise in regulatory requirements. Other stakeholder such as credit ratings, are asking for transparencies, and industries' top level management put more emphasize on an enhanced business value. That being said, financial services industry including banking has to strengthen its governance, its ability to manage risks and assure its compliance to the applied regulations.

Many studies on the correlation between governance and banking performance have already been performed. One of them are done by Orazalin, Mahmoud and Lee (2006) which is based on the Corporate Governance implementation at 30 banks in Russia between the period of 2004 and 2012. The finding emphasizes a positive relationship between stronger governance practice in banks with the bank's ability to tackle the harsh effect of the market crisis. Another similar findings also been discovered by Ayadi,Ayadi and Trabelsi (2019) which stated that internal mechanisms and capital regulations are complementary and significantly impact bank's performance.

Meanwhile, quite a handful of studies have also been conducted in the light of risk management and bank performance's linkage. A study done by Lundqvist and Vilhemsson (2016) empirically investigated the linkage between Enterprise Risk Management (ERM) practice and default risk in 78 largest banks in the world, using a panel data methodology. It is found that a higher extent of ERM practice is linked negatively with bank's credit default. Another result from a study on state-owned commercial banks in Indonesia stated that ERM implementation brings positive influence with regard to bank's performance (Liem, 2018). This study employs ERM Index as ERM practice's indicator, and the other indicators represents bank's performance are: NIM (Net Interest Margin), Return on Average Assets, and EM (Equity Multiplier). 
Further, a couple of studies regarding the correlation between compliance to regulations and bank performance have been conducted. Hassan (2019) examined how bank regulations impact bank's efficiency and performance in 93 banks around the world, and it is found that the regulations requiring banks to set up a certain amount of capital increase the productivity of banks in the North America and also Latin American. Further, supervisory enforcement also direct the growth of bank's productivity. This happens in banks around the world, except banks in Europe region and Central Asia.

On the other hand, a recent report conducted by Deloitte clearly stated that there are some trends that could have a significant impact on the business and operating environment for banking in 2021 and beyond. These trends, amongst all, are: (1) Growing needs of oversight in digital transformation and also technological innovation, (2) Increased spotlight on operational resilience, and (3) Regulatory uncertainty that drives financial resilience and generate new challenges

These evidences put forward a critical need for banks to apply a sound governance, risk management and compliance approach.

\section{Governance, Risk Management and Compliance as an Integrated Approach and It's Adoption in Global Banking Industry}

The concept of GRC as an integrated approach began to gain acknowledgement as Open Compliance and Ethics Group (OCEG), a non-profit organization think-tank in Governance, Risk Management, Compliance and Ethics, introduced an acronym called "GRC". OCEG then established GRC concept as an approach to the "Principled Performance", that is to achieve objectives, address uncertainty and act with integrity.

Many studies that conducted further has evidenced the criticality of having a clear vision on governance, risk management and compliance as an integrated approach, especially in banking industry. A study conducted by Hosseini et.al (2018) found that it is necessary for banks to align their management with the needs of relevant stakeholders, besides also assuring the safety and adequate performance of the banks. Further, he also pointed out that there are benefits of aligning integrated GRC with bank's operation, some of which are cost efficiency and reputational security.

The importance of practicing an integrated approach on GRC is also emphasized by Ahmadalinejad and Ghasempouri (2015) in their research about how GRC tools could be used in supervising Iran's virtual banks and effectively control their operations.

Further, Bezzina (2014) in his research regarding risk management adoption in Malta financial institutions, has stated that higher performance was expected by Malta's financial institutions once the "Principled Performance" have achieved.

In Indonesia, GRC as an integrated approach is a relatively new concept. Though, it is clearly stipulated by Rahmat (2019) that in the era of rapid volatility, uncertainty, complexity, and ambiguity (VUCA), Indonesian banks needs systematic effort to develop effective functions of corporate GRC in an integrated framework. One of the milestones in a roadmap towards GRC integrated implementation in Indonesia is the forming of "Indonesia GRC Forum", a working group initiated by Indonesia Financial Services Authority (IFSA/OJK), Indonesia's Banker Association for Risk Management (BARA), and Indonesia's Risk Management Professional Association (IRMAPA), amongst other institutions. In its book "The Guide to Achieve a GRC Excellence Model", Indonesia GRC Forum stated that Indonesian organizations currently implement governance, risk and compliance in silos, that results in weak coordination, overlapping works, conflicts, inevitable gaps and cost inefficiency. 


\section{ISO as International Standards for Integrated GRC}

ISO has released ISO 37000/DIS, ISO 31000:2018 Risk Management Principles and Guidelines, and ISO 37301: Compliance Management System as standards for Governance, Risk Management and Compliance. These three standards are fundamentally compatible each other and therefore could be used as a solid reference if organizations want to implement integrated GRC. Its compatibility as a standard is similar to a common structure of PDCA (Plan-Do-Check-Action) which consists of developing the plan (that includes exercising the principles and building the framework), executing the process, reviewing the process against the plan, and improving it.

Table 1. ISO 37000, ISO 31000, and ISO 37301 as Reference for Integrated GRC Practice

\begin{tabular}{|c|c|c|c|c|c|c|c|c|c|c|c|c|c|c|}
\hline \multirow{12}{*}{ 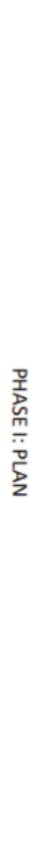 } & 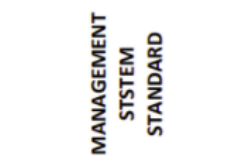 & 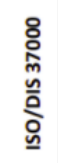 & 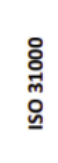 & 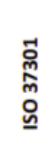 & \multirow{12}{*}{ 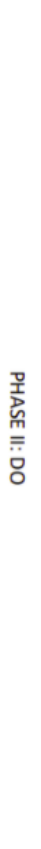 } & 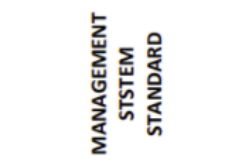 & 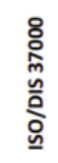 & 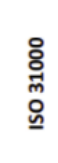 & 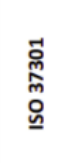 & \multirow{8}{*}{ 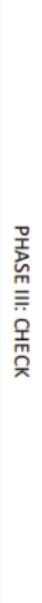 } & 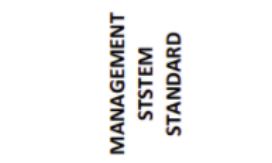 & 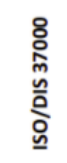 & 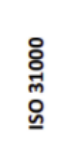 & 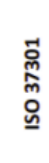 \\
\hline & \multicolumn{4}{|c|}{ 1. INTEGRATED MANAGEMENT POLICY } & & \multicolumn{4}{|l|}{ 3. SUPPORT \& OPERATION } & & \multicolumn{4}{|l|}{ 4. MONITORING \& REVIEW } \\
\hline & $\begin{array}{l}\text { Management system, } \\
\text { policy, and Management } \\
\text { commitment \& leadership }\end{array}$ & $\begin{array}{l}4.2 \\
7.7\end{array}$ & $\begin{array}{l}5 \\
5.2 \\
5.3 \\
5.4 .2\end{array}$ & $\begin{array}{l}4.4 \\
5.1 \\
5.2 \\
5.3\end{array}$ & & $\begin{array}{l}\text { 3.1. Resources (personnel, } \\
\text { infrastruture, cost) }\end{array}$ & $\begin{array}{l}5 \\
5.1\end{array}$ & 5.4 .4 & $\begin{array}{l}7.1 \\
7.2\end{array}$ & & $\begin{array}{l}\text { 4.1. Performance monitoring } \\
\text { and measurement of process } \\
\text { and procedures. }\end{array}$ & 7.4 & $\begin{array}{l}5.6 \\
6.6 .\end{array}$ & 9.1 \\
\hline & \multirow[t]{4}{*}{ 2. PLANNING } & & & & & \multirow{3}{*}{$\begin{array}{l}\text { 3.2. Competencies, } \\
\text { awareness, training. }\end{array}$} & \multirow[t]{3}{*}{5.2} & \multirow{3}{*}{$\begin{array}{l}4 \\
5.4 .4\end{array}$} & \multirow{3}{*}{$\begin{array}{l}7.2 \\
7.2 .3 \\
7.3\end{array}$} & & \multirow{3}{*}{$\begin{array}{l}\text { 4.2. Audit of non-compliance, } \\
\text { non-conformities, and } \\
\text { investigation }\end{array}$} & \multirow[t]{3}{*}{7.4 .3} & \multirow[t]{3}{*}{5.6} & \multirow{3}{*}{$\begin{array}{l}8.3 \\
8.4 \\
9.2\end{array}$} \\
\hline & & \multirow{3}{*}{$\begin{array}{l}4.1 \\
4.3\end{array}$} & \multirow{3}{*}{$\begin{array}{l}5.4 .1 \\
6.3 \\
6.3 .3\end{array}$} & \multirow{3}{*}{$\begin{array}{l}4.1 \\
4.2 \\
4.3 \\
4.5\end{array}$} & & & & & & & & & & \\
\hline & & & & & & & & & & & & & & \\
\hline & & & & & & $\begin{array}{l}\text { 3.3. Communication, } \\
\text { coordination, and } \\
\text { cooperation. }\end{array}$ & 7.5 & $\begin{array}{l}5.4 .5 \\
6.2\end{array}$ & 7.4 & & 4.3. Management review & 7.4 .3 & $\begin{array}{l}5.4 .2 \\
5.6\end{array}$ & $\begin{array}{l}9.3 .2 \\
9.3 .3\end{array}$ \\
\hline & $\begin{array}{l}\text { 2.2. Objectives and targets } \\
\text { setting }\end{array}$ & $\begin{array}{l}7.1 \\
7.2\end{array}$ & $\begin{array}{l}5.5 \\
6.4\end{array}$ & $\begin{array}{l}4.5 \\
6.2\end{array}$ & & $\begin{array}{l}\text { 3.4. Documented } \\
\text { information }\end{array}$ & 7.8 & 6.7 & 7.5 & & 4.4. Recording \& reporting & 7.5 .3 & 6.7 & 9.1 .5 \\
\hline & 2.3. Risk assessment & 7.3.3 & 6.4 & 4.6 & & 3.5. Control of documents & & 6.7 & 7.5 .3 & & 5. IMPROVEMENT & & & \\
\hline & $\begin{array}{l}\text { 2.4. Programs to address } \\
\text { risk and opporunities that } \\
\text { affect objectives/targets. }\end{array}$ & 7.3 & $\begin{array}{l}5.5 \\
6.5\end{array}$ & 6.1 & & $\begin{array}{l}\text { 3.5. Operational planning, } \\
\text { execution and control of } \\
\text { operation risks. }\end{array}$ & 7.9 & $\begin{array}{l}6.5 .2 \\
6.5 .3\end{array}$ & 8.1 & tz & 5.1. Improvement Plan & $\begin{array}{l}7.3 .3 \\
7.11\end{array}$ & 5.7 & 10.1 \\
\hline & $\begin{array}{l}\text { 2.5. Internal control plan to } \\
\text { address operation risk }\end{array}$ & 7.3 & $\begin{array}{l}6.5 .2 \\
6.5 .3\end{array}$ & $\begin{array}{l}8.1 \\
8.2\end{array}$ & & $\begin{array}{l}\text { 3.6. Operationalization of } \\
\text { contigency plan. }\end{array}$ & $\begin{array}{l}7.4 \\
7.4 .3\end{array}$ & 6.5 .3 & $\begin{array}{l}8.1 \\
8.4\end{array}$ & 状 & $\begin{array}{l}\text { 5.2. Correttive actions, } \\
\text { adaptation, and improvement. }\end{array}$ & 7.11 .3 & $\begin{array}{l}5.7 .1 \\
5.7 .2\end{array}$ & 10.2 \\
\hline & $\begin{array}{l}\text { 2.6. Emergency/ } \\
\text { contingency plan }\end{array}$ & $\begin{array}{l}7.4 \\
7.4 .3\end{array}$ & 6.5 .3 & $\begin{array}{l}8.1 \\
8.4\end{array}$ & & & & & & & & & & \\
\hline
\end{tabular}

(source: Dr. Antonius Alijoyo at https://crmsindonesia.org/publications/integrated-grc-using-iso-based-series-

of-standards-and-or-guidelines/)

While ISO 37000/DIS is still in its draft form (it is scheduled to be published on October 2021), ISO 31000:2018 Risk Management Principles and Guidelines, has been widely used in various fields and industries, and adopted by most countries (Susilo \& Riwu Kaho, 2018).

Indonesia have been endorsing ISO 31000:2018 as risk management standard used in organizations nationwide, namely SNI ISO 31000 (Standar Nasional Indonesia ISO 31000) in 2011 (Alijoyo and Fisabilillah, 2021). Though, apart from its extensive use in organizations in general, there is still not enough proof on its use as risk management standard in Indonesian banking industry.

On the other hand, ISO 37301: Compliance Management System is developed upon, and formally replaces ISO 19600:2014. The main and the most important difference between these two standards is that ISO 19600 provides only recommendations, as opposed to ISO 37301 which provides requirements for the implementation of a compliance management system (www.iso.org). Due to its newness, there is not much evidence with regards to its extensive use as Compliance Management standard in most organizations. 


\section{Indonesian Banking Regulation}

Banking industry in Indonesia are supervised and regulates by IFSA or Otoritas Jasa Keuangan /OJK). OJK have the authority in monitoring Indonesian bank's performance, and the regulation they issue is called Peraturan Otoritas Jasa Keuangan (POJK). POJK that specified on how management of risk is implemented in Indonesia commercial bank is POJK NOMOR 18 /POJK.03/2016 (or POJK 18 in short) about the practice of risk management for Indonesia commercial banks. POJK 18 specifies the process of commercial bank's risk management which includes risk identification, risk analysis, risk evaluation and risk treatment, besides also sets out the governance of risk.

Indonesian banks also adopted BASEL III (OJK Press Release, December 8, 2017). Basel III is a set of internationally recognized set of requirements issued by the Basel Committee on Banking Supervision (BCBS), a group of world's central banks, in response to the financial crisis of 2007-2009. The first Basel was introduced in July 1988, and it was constantly being revised until 2010, when Basel III was introduced. The Basel regulations were built upon a need of stringent capital requirement to withstand economic situation that leads to expected and unexpected period of losses. Tian (2017) also stated that capital buffer is needed to absorb the loss resulting from period of economic stress, and further to prevent massive liquidity deficiency that could lead to financial crises.

As stated above, instead of complying to POJKs and Basel III, it is arguably critical that Indonesian banking industry must as well adopt the ISO 37000, ISO 31000:2018 and ISO 37301 as its standard for integrated GRC practice. Though, it is still not enough proof whether these domestic regulations and the ISOs are compatible, complement, or contradict each other.

\section{RESEARCH METHODOLOGY}

In order to answer the research question posed in the Introduction, this study will utilize a comparative study method. Comparative study method is conducted by assessing the similarities and differences between two standards or regulations, or in this study, between Financial Services Authority Regulation in Indonesia, or Peraturan Otoritas Jasa Keuangan (POJK), and the ISO Standards related to Governance, Risk Management and Compliance. The result is expected to show degree of fitness of POJK with its counterparts ISO standards.

The comparative study is conducted by matching each clause in POJK with its ISO counterpart, which are: 1. POJK No.55/POJK.03/2016 (or POJK 55) about the Implementation of Governance in Indonesian banks with ISO 37000/ DIS about Governance of Organizations

2. POJK NOMOR 18 /POJK.03/2016 (or POJK 18) about the Implementation of Risk Management in Indonesian Commercial Banks and ISO 31000:2018 Risk Management Principles and Guidelines

3. POJK No.46/POJK.03/2017 (or POJK 46) about Compliance Function in Indonesian Commercial Banks with ISO 37301: 2021 about Compliance Management System

As an illustration, one of the comparation process is between the POJK 18 (the Implementation of Risk Management in Indonesian Commercial Banks), with ISO 31000:2018 Risk Management Principles and Guidelines. The process is done through examining every Clause listed in POJK 18, and then compare it with each clause in Principles, Framework and Process of ISO 310002018.

For instance, the Clause 2.2 of POJK 18 is:

"The application of Risk Management as referred to Clause 1 shall at least include: (a) active supervision of the Board of Directors and the Board of Commissioners, (b) adequacy of Risk Management policies and procedures and determination of Risk limits, (c) the adequacy of the Risk identification, measurement, monitoring, and 
control processes, as well as the Risk Management information system; and (d) comprehensive internal control system".

It could be seen that, for example, Clause 2.2 of POJK 18 aligns with some of ISO 31000:2018 Clauses, which are: (1) Principles of Risk Management, which is "Structured and Comprehensive", (2) Framework of Risk Management, which is "Design", and (3) Process of the Management (all clauses).

This comparison process is repeated for all the clauses in POJKs and their ISO counterparts, for each Governance, Risk Management and Compliance domain. The expected results will show the degree of fitness between POJK and ISO standards in Governance, Risk Management and Compliance, which will be presented in three individual tables.

\section{Validity and Reliability Testing}

Reliability and validity are trustworthiness, rigor and quality in qualitative model, in order to eliminate bias and increase researcher's truthfulness (Denzin, 1978). One way to gain reliability and validity in qualitative research is through the triangulation method. Triangulation may take several forms, but some procedure that are commonly used are utilizing multiple data source, data collection methods or investigators (T. Long, M. Johnson, 2000).

This study utilizes one form of triangulation method, which is the employment of multiple investigators, or "peer review". The views and advises from peer review regarding the study are accommodated, to such an extent that a more thorough perspective and hence, a more valid and reliable research method and result are expected.

\section{Finding and Discussion}

As explained in the research method, in order to measure the degree of fitness between Indonesian banking regulation and ISO-based standards for GRC, three comparative studies are performed.

The first one is a comparation between POJK 55 and ISO 37000. The comparative study is conducted by mapping up all the clauses in POJK55 with ISO 37000 components. The second one is comparing POJK 18 with ISO 31000:2018 with, and the third one is comparing POJK 46 with ISO 37301.

The results are depicted in the Table 2, Table 3 and Table 4, respectively. 
RSF Conference Series: Business, Management and Social Sciences Vol. 1 (5), 84-96

Comparison of Indonesian Banking Regulation for Integrated Governance, Risk Management, Compliance with its ISO Counterparts

Nitha Pricillia

Table 2. Comparison Matrix between POJK No.55/POJK.03/2016 and ISO 37000/DIS

\begin{tabular}{|c|c|c|c|c|c|c|c|c|c|c|c|c|c|c|}
\hline & & & & & & & OJK C & ause 1 & & & & & & \\
\hline iso & $\begin{array}{l}\text { Cla } \\
\text { use. } \\
1-3\end{array}$ & $\begin{array}{l}\text { Cla } \\
\text { use } \\
4- \\
22\end{array}$ & $\begin{array}{l}\text { Clau } \\
\text { se. } \\
23- \\
40\end{array}$ & $\begin{array}{l}\text { Cla } \\
\text { use. } \\
41- \\
51\end{array}$ & \begin{tabular}{|l} 
Claus \\
e. \\
$52-$ \\
55
\end{tabular} & \begin{tabular}{|l|} 
Cla \\
use \\
. \\
$56-$ \\
58 \\
\end{tabular} & $\begin{array}{l}\text { Clau } \\
\text { se. } \\
59\end{array}$ & \begin{tabular}{|l|} 
Clau \\
se. \\
$60-$ \\
61
\end{tabular} & $\begin{array}{l}\text { Clau } \\
\text { se. } \\
62- \\
63\end{array}$ & $\begin{array}{l}\text { Clau } \\
\text { se. } \\
64- \\
68\end{array}$ & $\begin{array}{l}\text { Clau } \\
\text { se. } \\
69- \\
70\end{array}$ & $\begin{array}{l}\text { Clau } \\
\text { se. } \\
71- \\
77\end{array}$ & $\begin{array}{l}\text { Clau } \\
\text { se. } \\
78\end{array}$ & $\begin{array}{r}\text { Cla } \\
\text { use } \\
.79 \\
-81\end{array}$ \\
\hline $\begin{array}{l}\text { 3. Terms and } \\
\text { definitions }\end{array}$ & & & & & & & & & & & & & & \\
\hline $\begin{array}{l}3.1 \\
\text { Governance } \\
\text { and } \\
\text { organization }\end{array}$ & 0 & & & & & & & & & & & & & \\
\hline $\begin{array}{l}3.2 \text { Principles } \\
\text { and outcomes }\end{array}$ & 0 & & & & & & & & & & & & & \\
\hline 3.3 Roles & 0 & 0 & 0 & 0 & 0 & 0 & & & & & & & & \\
\hline $\begin{array}{l}\text { 4. Context of } \\
\text { this standard }\end{array}$ & 0 & & & & & & & & & & & & & 0 \\
\hline $\begin{array}{l}\text { 4.1 The need } \\
\text { for guidance }\end{array}$ & & & & & & & & & & & & & & 0 \\
\hline $\begin{array}{l}4.2 \text { The } \\
\text { governance of } \\
\text { organizations }\end{array}$ & 0 & 0 & 0 & 0 & 0 & & & & & & & & & \\
\hline $\begin{array}{l}4.3 \\
\text { Governance } \\
\text { and } \\
\text { stakeholders }\end{array}$ & 0 & 0 & & & 0 & & & & & & & & & \\
\hline $\begin{array}{l}\text { 5. The } \\
\text { governing } \\
\text { body; } \\
\text { composition } \\
\text { and structure }\end{array}$ & & 0 & 0 & 0 & 0 & & & & & & & & 0 & \\
\hline $\begin{array}{l}5.1 \\
\text { Competence }\end{array}$ & & 0 & 0 & 0 & 0 & & & & & & & & & \\
\hline 6.Frame-work & & & & & 0 & 0 & & & & & & & & \\
\hline $\begin{array}{l}\text { 7. Principles } \\
\text { of } \\
\text { governance }\end{array}$ & & & & & & & & & & & & & & \\
\hline 7.1 Purpose & 0 & & & & 0 & 0 & & & & & & & & \\
\hline $\begin{array}{l}7.2 \text { Value } \\
\text { generation }\end{array}$ & 0 & & & & 0 & 0 & & & & & & & & \\
\hline 7.3 Strategy & 0 & & & & 0 & 0 & 0 & 0 & 0 & & & & & \\
\hline 7.4 Oversight & 0 & 0 & 0 & 0 & & & & & 0 & 0 & 0 & 0 & 0 & \\
\hline $\begin{array}{l}7.5 \\
\text { Accountability }\end{array}$ & 0 & 0 & 0 & 0 & & & 0 & 0 & 0 & 0 & 0 & 0 & 0 & \\
\hline $\begin{array}{l}7.6 \\
\text { Stakeholder } \\
\text { engagement }\end{array}$ & 0 & 0 & 0 & 0 & 0 & & & 0 & 0 & 0 & 0 & 0 & & \\
\hline $\begin{array}{l}7.7 \\
\text { Leadership }\end{array}$ & 0 & 0 & 0 & 0 & & & & & 0 & 0 & 0 & 0 & 0 & \\
\hline
\end{tabular}


RSF Conference Series: Business, Management and Social Sciences Vol. 1 (5), 84-96

Comparison of Indonesian Banking Regulation for Integrated Governance, Risk Management, Compliance with its ISO Counterparts

Nitha Pricillia

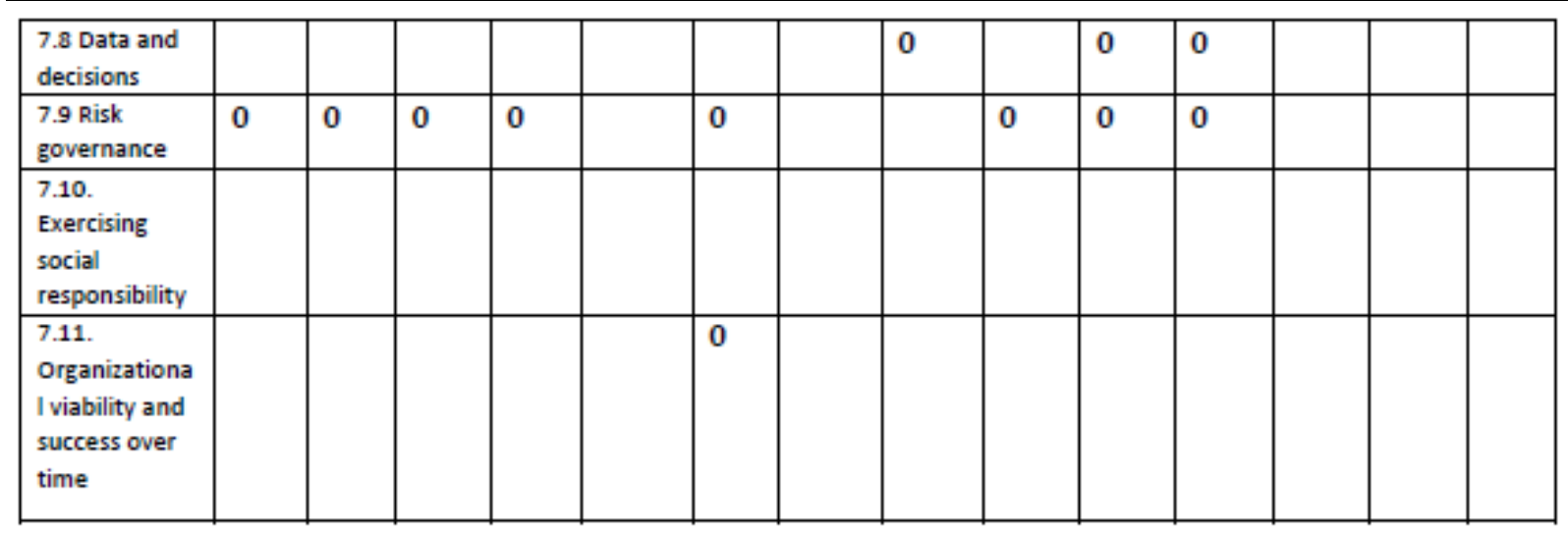

"0" = "accommodated in"

"X" = "contradict with"

From Table 2, it could be seen that all the Clauses in POJK are accommodated in ISO 37000/DIS about Governance of Organizations.

Further, the comparative study between POJK 18 and ISO 31000:2018 Risk Management Principles and Guidelines is presented in the Table 3 below. 
RSF Conference Series: Business, Management and Social Sciences Vol. 1 (5), 84-96

Comparison of Indonesian Banking Regulation for Integrated Governance, Risk Management, Compliance with its ISO Counterparts

Nitha Pricillia

Table 3. Comparison Matrix between POJK No.18/POJK.03/2016 and ISO 31000: 2018

\begin{tabular}{|c|c|c|c|c|c|c|c|c|c|c|c|c|}
\hline \multirow{2}{*}{ РОJK } & \multicolumn{12}{|c|}{ POJK Clause 1-35 } \\
\hline & $\begin{array}{l}\text { Cla } \\
\text { use } \\
1\end{array}$ & $\begin{array}{l}\text { Cla } \\
\text { use } \\
2-4\end{array}$ & $\begin{array}{l}\text { Claus } \\
\text { e 5- } \\
7\end{array}$ & $\begin{array}{l}\text { Claus } \\
\text { e 8-9 }\end{array}$ & $\begin{array}{l}\text { Claus } \\
\text { e } 10 \\
-12\end{array}$ & $\begin{array}{l}\text { Claus } \\
\text { e } 13- \\
15\end{array}$ & $\begin{array}{l}\text { Claus } \\
\text { e } 16 \\
-19\end{array}$ & $\begin{array}{l}\text { Claus } \\
\text { e } 20- \\
22\end{array}$ & $\begin{array}{l}\text { Claus } \\
\text { e } 23- \\
27\end{array}$ & $\begin{array}{l}\text { Clause } \\
28-30\end{array}$ & $\begin{array}{l}\text { Clause } \\
31-32\end{array}$ & $\begin{array}{l}\text { Clause } \\
33-35\end{array}$ \\
\hline \multicolumn{13}{|l|}{ Principles } \\
\hline Integrated & & 0 & & & & 0 & & & & & & \\
\hline $\begin{array}{l}\text { Structured and } \\
\text { Comprehensive }\end{array}$ & & 0 & 0 & 0 & 0 & & 0 & & & & & 0 \\
\hline Customized & 0 & 0 & & & & 0 & 0 & & & & & \\
\hline Inclusive & & & & & & 0 & & & & & & \\
\hline \multicolumn{13}{|l|}{ Dynamic } \\
\hline $\begin{array}{l}\text { Best Available } \\
\text { Information }\end{array}$ & & & & & 0 & 0 & & & & 0 & & \\
\hline $\begin{array}{l}\text { Human and } \\
\text { Cultural Factors }\end{array}$ & & & & & & & 0 & & & & & \\
\hline $\begin{array}{l}\text { Continual } \\
\text { Improvement }\end{array}$ & & & & & 0 & & & & & & & \\
\hline \multicolumn{13}{|l|}{ Framework } \\
\hline \multicolumn{13}{|l|}{ Integration } \\
\hline Design & 0 & 0 & 0 & 0 & & 0 & 0 & 0 & 0 & 0 & & \\
\hline Implementation & & 0 & & & 0 & & & 0 & 0 & & & 0 \\
\hline \multicolumn{13}{|l|}{ Evaluation } \\
\hline \multicolumn{13}{|l|}{ Improvement } \\
\hline \multicolumn{13}{|l|}{ Process } \\
\hline $\begin{array}{l}\text { Scope, Context } \\
\text { and Criteria }\end{array}$ & 0 & 0 & 0 & 0 & 0 & & 0 & 0 & 0 & 0 & & 0 \\
\hline Risk Assesment & & 0 & & & 0 & & & 0 & & & & \\
\hline Risk Treatment & & & & & 0 & & & & & & & \\
\hline $\begin{array}{l}\text { Recording and } \\
\text { Reporting }\end{array}$ & & & & & 0 & 0 & & & 0 & & 0 & \\
\hline $\begin{array}{l}\text { Communication } \\
\text { and Consultation }\end{array}$ & & & & & & & 0 & & 0 & & & \\
\hline $\begin{array}{l}\text { Monitoring and } \\
\text { Review }\end{array}$ & & & & & & 0 & 0 & & & & & \\
\hline
\end{tabular}

“0" = "accommodated in"

"X" = "contradict with" 
RSF Conference Series: Business, Management and Social Sciences Vol. 1 (5), 84-96

Comparison of Indonesian Banking Regulation for Integrated Governance, Risk Management, Compliance with its ISO Counterparts

Nitha Pricillia

As could be seen in Table 3, all the Clauses in POJK 18 are accommodated in the ISO 31000:2018. Therefore, it could be presumed that POJK 18 is compatible with ISO 31000:2018.

Lastly, a comparative study between POJK 46 and ISO 37301 on the Compliance Management System is presented in the Table 4 below.

Table 4. Comparison Matrix between POJK No.46/POJK.03/2017 and ISO 37301

\begin{tabular}{|c|c|c|c|c|c|c|c|c|}
\hline \multirow{3}{*}{ Iso } & \multicolumn{8}{|c|}{ POJK Clause 1-22 } \\
\hline & $\begin{array}{l}\text { Clause } \\
1-2\end{array}$ & $\begin{array}{l}\text { Clause } \\
3-6\end{array}$ & $\begin{array}{l}\text { Clause } 7 \\
-11\end{array}$ & $\begin{array}{l}\text { Clause } \\
12-15\end{array}$ & $\begin{array}{l}\text { Clause } \\
16-17\end{array}$ & $\begin{array}{l}\text { Clause } \\
18\end{array}$ & $\begin{array}{l}\text { Clause } \\
19-20\end{array}$ & $\begin{array}{l}\text { Clause } \\
21-22\end{array}$ \\
\hline & & & & & & & & \\
\hline $\begin{array}{l}\text { 4.1. Understanding } \\
\text { the organization } \\
\text { and its context; }\end{array}$ & 0 & & & & & & & \\
\hline $\begin{array}{l}4.2 \text { Understanding } \\
\text { the needs and } \\
\text { expectations of } \\
\text { interested parties }\end{array}$ & $\mathbf{0}$ & & & & & & & \\
\hline $\begin{array}{l}\text { 4.3 Determining } \\
\text { the scope of the } \\
\text { compliance } \\
\text { management } \\
\text { system }\end{array}$ & & 0 & & & & & & $\mathbf{0}$ \\
\hline $\begin{array}{l}4.4 \text { Compliance } \\
\text { management } \\
\text { system }\end{array}$ & & 0 & & & & & & \\
\hline $\begin{array}{l}4.5 \text { Compliance } \\
\text { obligations }\end{array}$ & & 0 & & & & & 0 & \\
\hline $\begin{array}{l}4.6 \text { Compliance } \\
\text { risk assessment }\end{array}$ & & & & & & & & \\
\hline $\begin{array}{l}5.1 \text { Leadership } \\
\text { and commitment }\end{array}$ & & 0 & $\mathbf{0}$ & $\mathbf{0}$ & & & & \\
\hline $\begin{array}{l}\text { 5.1.1. Governing } \\
\text { body and top } \\
\text { management }\end{array}$ & & & $\mathbf{0}$ & $\mathbf{0}$ & & & & \\
\hline $\begin{array}{l}\text { 5.2.2.Compliance } \\
\text { culture }\end{array}$ & & & & $\mathbf{0}$ & & & & \\
\hline $\begin{array}{l}\text { 5.3.3.Compliance } \\
\text { Governance }\end{array}$ & & & 0 & 0 & & & & \\
\hline $\begin{array}{l}5.2 \text { Compliance } \\
\text { policy }\end{array}$ & & 0 & $\mathbf{0}$ & $\mathbf{0}$ & & & 0 & \\
\hline $\begin{array}{l}5.3 \text { Roles, } \\
\text { responsibilities } \\
\text { and authorities }\end{array}$ & & 0 & 0 & $\mathbf{0}$ & & & & $\mathbf{0}$ \\
\hline $\begin{array}{l}\text { Governing body } \\
\text { and top } \\
\text { management }\end{array}$ & & 0 & $\mathbf{0}$ & $\mathbf{0}$ & & & & \\
\hline $\begin{array}{l}\text { Compliance } \\
\text { function }\end{array}$ & & 0 & $\mathbf{0}$ & $\mathbf{0}$ & & & & \\
\hline Management & & 0 & 0 & $\mathbf{0}$ & & & & \\
\hline Personel & & 0 & 0 & $\mathbf{0}$ & & & & \\
\hline $\begin{array}{l}6.1 \text { Actions to } \\
\text { address risks and } \\
\text { opportunities }\end{array}$ & & & & $\mathbf{0}$ & & & & \\
\hline $\begin{array}{l}6.2 \text { Compliance } \\
\text { objectives and }\end{array}$ & & & & $\mathbf{0}$ & & & & \\
\hline
\end{tabular}


RSF Conference Series: Business, Management and Social Sciences Vol. 1 (5), 84-96

Comparison of Indonesian Banking Regulation for Integrated Governance, Risk Management, Compliance with its ISO Counterparts

Nitha Pricillia

\begin{tabular}{|c|c|c|c|c|c|}
\hline $\begin{array}{l}\text { planning to } \\
\text { achieve them }\end{array}$ & & & & & \\
\hline $\begin{array}{l}6.3 \text { Planning of } \\
\text { changes }\end{array}$ & 0 & 0 & & & \\
\hline 7.1 Resources & 0 & 0 & & & \\
\hline 7.2 Competence & 0 & 0 & & & \\
\hline 7.2.1 General & 0 & 0 & & & \\
\hline $\begin{array}{l}7.2 .2 \text { Employment } \\
\text { process }\end{array}$ & 0 & 0 & & & \\
\hline 7.2.3 Training & & & & & \\
\hline 7.3 Awareness & & & & & \\
\hline $\begin{array}{l}7.4 \\
\text { Communication }\end{array}$ & 0 & 0 & & & \\
\hline $\begin{array}{l}7.5 \text { Documented } \\
\text { information }\end{array}$ & & & 0 & 0 & \\
\hline 7.5.1 General & & & 0 & 0 & \\
\hline $\begin{array}{l}7.5 .2 \text { Creating and } \\
\text { updating } \\
\text { documented } \\
\text { information }\end{array}$ & & 0 & 0 & 0 & \\
\hline $\begin{array}{l}\text { 7.5.3 Control of } \\
\text { documented } \\
\text { information }\end{array}$ & & 0 & 0 & 0 & \\
\hline $\begin{array}{l}\text { 8.1 Operational } \\
\text { planning and } \\
\text { control }\end{array}$ & & 0 & & & \\
\hline $\begin{array}{l}\text { 8.2 Establishing } \\
\text { controls and } \\
\text { procedures }\end{array}$ & & 0 & & & 0 \\
\hline $\begin{array}{l}\text { 8.3 Raising } \\
\text { concerns }\end{array}$ & & 0 & & & \\
\hline $\begin{array}{l}8.4 \text { Investigation } \\
\text { processes }\end{array}$ & & 0 & & & \\
\hline $\begin{array}{l}\text { 9.1 Monitoring, } \\
\text { measurement, } \\
\text { analysis and } \\
\text { evaluation }\end{array}$ & & 0 & & & 0 \\
\hline 9.1.1 General & & 0 & & & \\
\hline
\end{tabular}


Comparison of Indonesian Banking Regulation for Integrated Governance, Risk Management, Compliance with its ISO Counterparts

Nitha Pricillia

\begin{tabular}{|c|c|c|c|c|c|}
\hline $\begin{array}{l}\text { 9.1.2 Sources of } \\
\text { feedback on } \\
\text { compliance } \\
\text { performance }\end{array}$ & & 0 & & & \\
\hline $\begin{array}{l}9.1 .3 \\
\text { Development of } \\
\text { indicators }\end{array}$ & & 0 & & & \\
\hline $\begin{array}{l}9.1 .4 \text { Compliance } \\
\text { reporting }\end{array}$ & 0 & & 0 & 0 & \\
\hline $\begin{array}{l}\text { 9.1.5 Record } \\
\text { Keeping }\end{array}$ & & & 0 & 0 & \\
\hline 9.2 Internal audit & & & & & \\
\hline 9.2.1 General & & & & & \\
\hline $\begin{array}{l}9.2 .2 \text { Internal } \\
\text { audit programme }\end{array}$ & & & & & \\
\hline $\begin{array}{l}\text { 9.3 Management } \\
\text { Review }\end{array}$ & & 0 & & & \\
\hline 9.3.1 General & & 0 & & & \\
\hline $\begin{array}{l}9.3 .2 \\
\text { Management } \\
\text { Review Inputs }\end{array}$ & & 0 & & & \\
\hline $\begin{array}{l}9.3 .3 \\
\text { Management } \\
\text { Review Results }\end{array}$ & & 0 & & & \\
\hline $\begin{array}{l}10.1 \text { Continual } \\
\text { improvement }\end{array}$ & & 0 & & & \\
\hline $\begin{array}{l}10.2 \\
\text { Nonconformity } \\
\text { and corrective } \\
\text { action }\end{array}$ & & 0 & & & 0 \\
\hline
\end{tabular}

"0" = "accommodated in"

\section{"X" = "contradict with"}

As could be seen in Table 4, all the Clauses in POJK 46 are accommodated in ISO 37301 Compliance Management System.

\section{CONCLUSION}

Based on the above comparison matrix presented in Tables 2, 3 and 4, it could be seen that all POJK Clauses for both POJK 55 (Governance Implementation), POJK 18 (Risk Management Implementation), and POJK 46 (Compliance Management) are all accommodated in the ISO 37000/DIS on Governance of Organizations , ISO 31000:2018 Risk Management Principles and Guidelines, and ISO 37301: 2021 about Compliance Management System, respectively. 


\section{Limitation and Further Study}

Whereas the study provides general understanding and assurance of the compatibility, it is not supported yet by empirical evidence of how banks practically exercise the implementation of integrated GRC based on ISO series 37000, ISO 31000, and ISO 37301 and how do they conduct calibration efforts to its efficacy. Therefore, it is recommended to conduct such empirical case study in several banks in Indonesia as further study. Further, a field study such as interviews and surveys with banking professionals are also recommended to be performed, to provide additional perspectives on how integrated GRC is implemented in Indonesian banking industry.

\section{REFERENCES}

Alijoyo , F. Antonius \& Fisabilillah, Al Fattaah M.S (2021. Risk Management Implementation in Public Sector Organizations-Global Phenomena. International Journal of Current Science Research and Review, Volume 04 Issue 03 March 2021.

Deloitte (2021). Banking Regulatory Outlook 2021 Report. Retrieved from https://www2.deloitte.com/us/en/pages/regulatory/articles/banking-regulatory-outlook.html

Hosseini et.al (2018). The Establishment of GRC Integrated Approach in Iranian Bank's for Smoothing the Interaction with the International Banking System. Journal of Management Research, Macrothink Institute, 2018, Vol. 10, No. 1

Ahmadalinejad, M, and Ghasempouri, S.A (2015). Modeling Trust in Supervising of Virtual Banking Systems: A GRC Based Approach. The 9th International Conference on e-Commerce in Developing Countries: with focus on e-Business (ECDC) at Isfahan, Iran.

Rahmat, Mujid (2019). A Conceptual Model of Governance, Risk and Compliance (GRC) Integration Maturity for Banking Organization in Indonesia. Conference: 2nd International Conference on Multidisciplinary Academic Research (ICMAR-2019) at Bali, Indonesia

Indonesia GRC Forum (2019). The Guide to Achieve a GRC Excellence Model. Retrieved from https://irmapa.org/panduan-mencapai-model-keunggulan-governance-risk-management-andcompliance-grc/

Tian, Weidong (2017). Commercial Banking Risk Management; Regulation in the Wake of the Financial Crisis. Palgrave-MacMillan, New York.

Bezzina, F, Grima, S and Mamo, J (2013). Risk Management Practices Adopted by Financial Firms In Malta. Managerial Finance, Vol. 40 Iss 6 pp. 587 - 612

Denzin, N. K. (1978). The research act: A theoretical introduction to sociological methods. New York: McGraw-Hill

Long, T and Johnson, M (2000). Rigour, Reliability and Validity in Qualitative Research. Clinical Effectivenes in Nursing Journal, Vol.4, Issue.1, March 2000, Page 30 -37

Dr. Antonius Alijoyo (2021) at https://crmsindonesia.org/publications/integrated-grc-using-iso-basedseries-of-standards-and-or-guidelines/

Mohamed A. Ayadi, Nesrine Ayadi, Samir Trabelsi, (2019) "Corporate governance, European bank performance and the financial crisis", Managerial Auditing Journal, https://doi.org/10.1108/ MAJ11-2017-1704

Nurlan Orazalin Monowar Mahmood Keun Jung Lee , (2016),"Corporate governance, financial crises and bank performance: Lessons from top Russian banks", The International Journal of Business in Society, Vol. 16 Iss 5 pp.

Liem, Christina (2018). Enterprise Risk Management in Banking Industry, Journal of Management Studies (FIRM), Vol.3 No.1

Hassan, Mohamad (2020). "How bank regulations impact efficiency and performance?", Lournal of Financial Economic Policy, Vol. 12 No. 4, pp. 545-575. https://doi.org/10.1108/JFEP-06-2019-0119 